\title{
ANALISA E-CONOMY DI ASEAN \\ (Studi Komparatif di Enam Negara ASEAN)
}

\author{
${ }^{1}$ Jati Imantoro, ${ }^{2}$ Karnila Ali, ${ }^{3}$ Mei Handayani \\ Universitas Muhammadiyah Metro \\ e-mail: karnila.ali85@gmail.com
}

\section{FIDUSIA}

Jurnal Ilmiah Keuangan dan Perbankan

ISSN Cetak : 2621-2439

ISSN Online : 2621-2447

Keywords: E-conomy, ASEAN,

Financial Technology, Growth
ABSTRACT

This study aims to analyze the development of e-conomy in ASEAN in terms of population use, capitalization value, e-conomy growth, consumer motivation in internet use, and fintech. This research uses descriptive qualitative by using comparative and qualitative methods, namely comparing a debate and analyzing data and matters relating to the numbers used to analyze the problem being carried out. The sample in this study was six ASEAN countries containing Thailand, Vietnam, Singapore, Indonesia, Philippines and Malaysia. E-conomy is getting faster and faster, faster and faster can make money through the internet, growth opportunities outside Metros, and Financial Technology using the era of disruption.

Keywords: E-conomy, ASEAN, Financial Technology, Growth 


\section{PENDAHULUAN}

Negara ASEAN dengan populasi sekitar 570 juta orang, dimana terdapat enam negara di ASEAN dengan ekonomi terbesar di Asia Tenggara yang terdiri dari Indonesia, Malaysia, Filipina, Thailand, Vietnam dan Singapura adalah salah satu pasar dengan pertumbuhan tercepat di dunia hal tersebut bisa dilihat dari gambar dibawah ini:

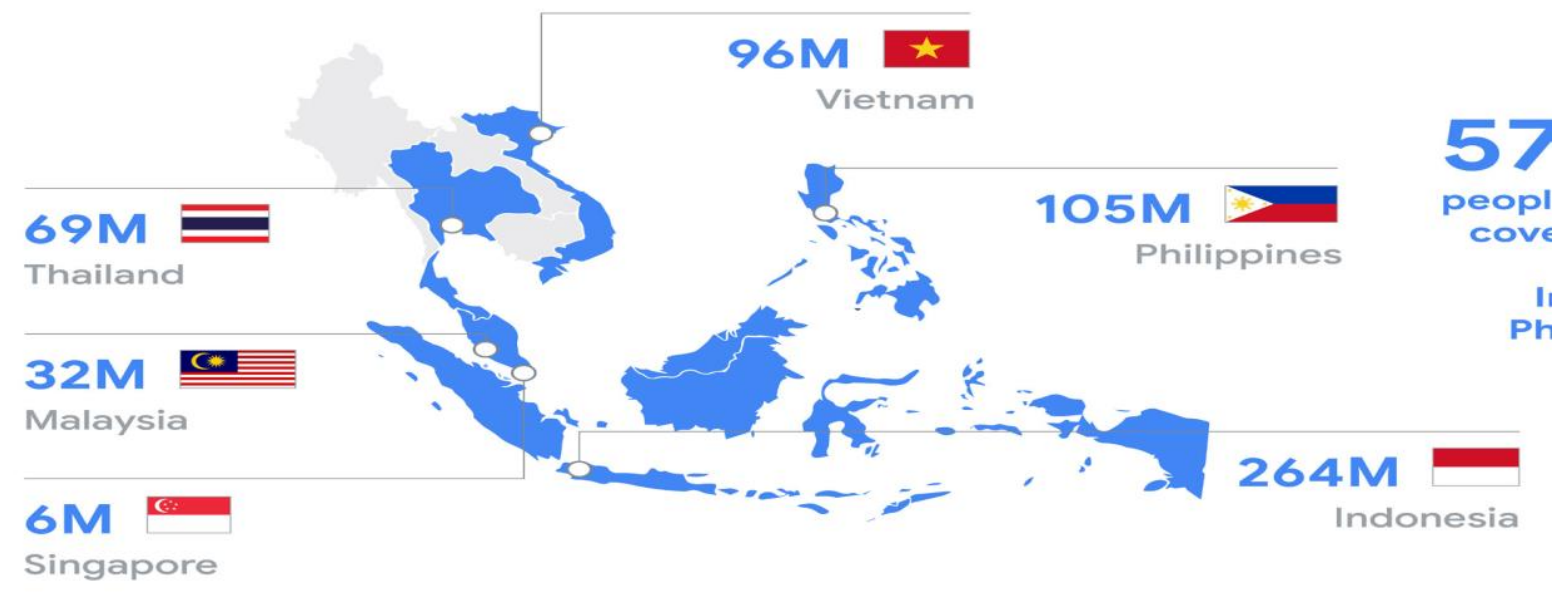

Gambar 1.1 Populasi Pasar Potensial di ASEAN

Sumber: Temasek: 2019

Pertumbuhan ekonomi di kawasan ini rata-rata $5 \%$ per tahun dalam lima tahun terakhir dan telah melampaui pertumbuhan ekonomi global dimana rata-rata pertumbuhan sekitar 2 persentase selama dekade terakhir. Ini merupakan salahn satu indikasi stabilitas serta wilayah yang berkembang pesat dalam perjalanan untuk menjadi lokomotif ekonomi utama pada 2030, Abrar, Hafiza.(2016). Asia Tenggara diharapkan menjadi blok ekonomi terbesar keempat di dunia hal tersebut bisa dilihat dari gambar dibawah ini

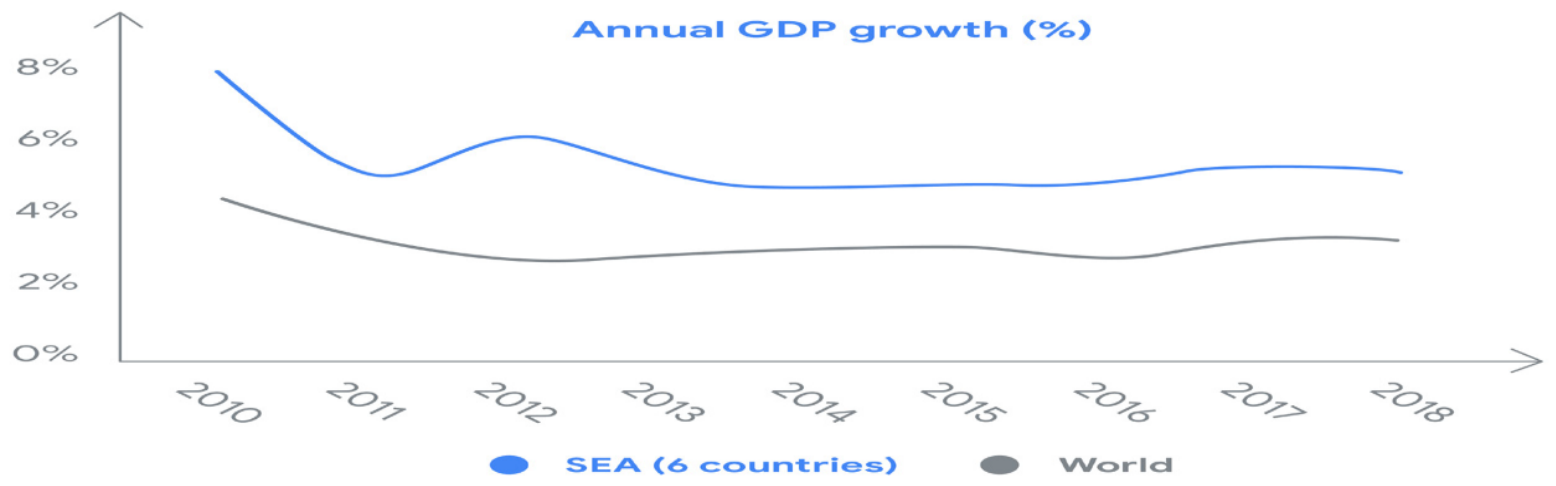

Gambar 1.2 Perbandingan GDP Global dengan ASEAN

Sumber: Bain \& Company:2019

Fenomena lain adalah Asia Tenggara tumbuh paling cepat dengan terhubungnya serta komunitas yang mendukung Internet yang telah berakar dalam beberapa tahun terakhir dan ini berkembang pesat. Satu dekade lalu, hampir empat dari lima orang Asia Tenggara tidak 
memiliki konektivitas Internet dan akses terbatas ke informasi. Saat ini, masyarakat Asia Tenggara adalah pengguna Internet seluler yang paling besar di dunia (Allen, Franklin, et al. 2013)

Dari hampir 400 juta orang dewasa di Asia Tenggara, hanya 104 juta yang sepenuhnya " menikmati akses penuh untuk Layanan Keuangan. 98 juta lainnya adalah "Underbanked" yaitu dimana populasi tersebut mempunyai rekening bank tetapi aksesnya tidak memadai untuk mendapatkan kredit, investasi dan asuransi, sementara 198 juta tetap " tidak memiliki rekening bank. Jutaan perusahaan kecil dan menengah juga menghadapi kesenjangan pendanaan yang besar hal tersebut bisa dilihat dari gambar 1.1 dibawah ini,

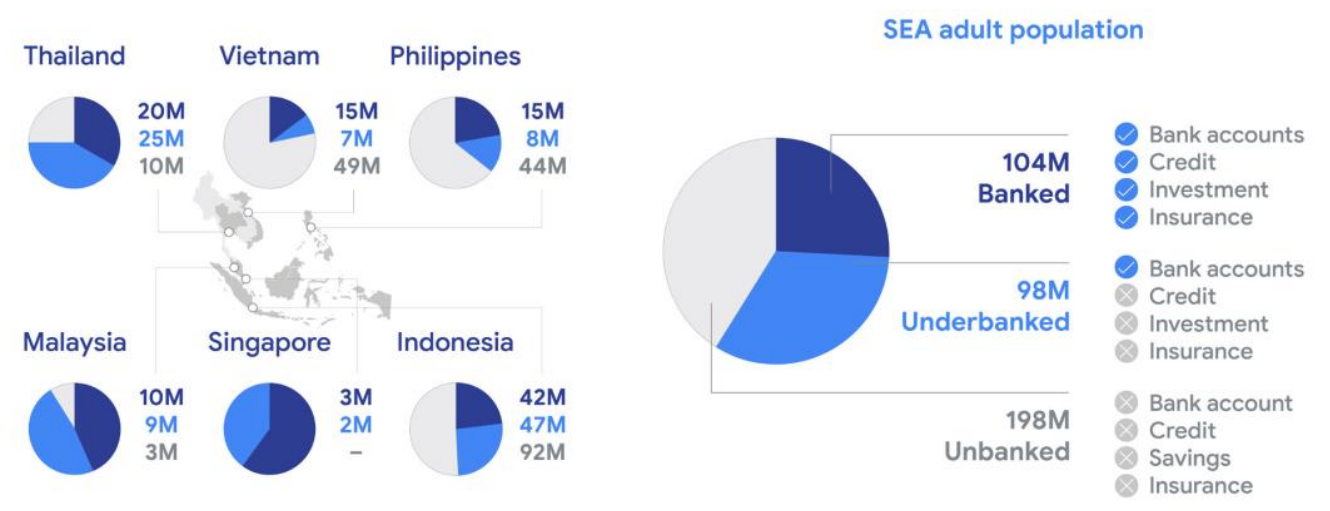

Gambar 1.3 Perkembangan Populasi Pengguna Jasa Keuangan di ASEAN

Sumber: Temasek: 2019

Diwilayah yang luas di mana sebagian besar infrastruktur fisik yang masih kekurangan, dikarenakan hal tersebut menggunakan biaya sangat mahal bagi lembaga keuangan untuk membangun cabang fisik yang dapat melayani semua pelanggan. Tantangan lain termasuk tidak adanya register publik, sistem identifikasi dan dapat diandalkan informasi kredit, yang semuanya merupakan prasyarat dasar untuk lembaga keuangan Cao Lu, dan Zhou Xin. (2010). Apalagi perbankan adalah sektor yang diatur ketat di banyak negara Asia Tenggara. Persaingan dan inovasi merupakan faktor penting, sehingga akibatnya, perkembangan industri perbankan tertahan. Semakin sadar tentang kebutuhan keuangan mereka, masyarakat Asia Tenggara menjadi lebih proaktif untuk mempertimbangkan Jasa Keuangan mana yang terbaik untuk mereka berdasarkan penelitian Bardiev, A. N., dan Saunoris, J.W. (2016). Walaupun saat ini Jasa Keuangan kebanyakan masayarkat melakukan transaksi secara offline, namun transaksi online semakin meningkat. Penelitian menunjukkan bahwa $60 \%$ orang Singapura dan $50 \%$ orang Vietnam melakukan riset online sebelum melakukan pembelian secara offline. Bukan itu saja. Sekitar $72 \%$ konsumen di Indonesia melihat Google Search sebagai gateway online untuk informasi kredit dan sumber informasi kedua yang paling bermanfaat untuk Layanan Keuangan setelah cabang bank. Aplikasi yang muncul sekarang ini membantu konsumen menemukan tempat dan bisnis atau menyarankan rute terbaik menuju destinasi yang diinginkan dimana juga menjadi hal pokok bagi banyak 
pengguna di Asia Tenggara. Waze dan Google Maps, misalnya, mereka menggunakan peta yang terbaru, informasi lalu lintas waktu real time dan jadwal transportasi umum untuk membantu jutaan orang menghemat waktu (D. H. Vo, dan T. H. Ly:2014). Dalam perjalanan sehari-hari mereka. Aplikasi semacam itu juga berfungsi sebagai alat yang kuat untuk bisnis kecil dan menengah (UKM) di wilayah tersebut. Mereka memungkinkan pengguna untuk menemukan SMB, memeriksa lokasi mereka dan jam buka, serta menghubungi mereka untuk bertanya tentang produk dan layanan mereka, mengulas dan bahkan memesannya, seperti dalam kasus banyak orang pada restoran dan hotel. Pada saat yang sama, banyak orang Asia Tenggara mengandalkan aplikasi berbasis cloud yang tersedia secara bebas dan luas tepercaya, seperti Gmail, Google Documents, dan Google Sheets, untuk bekerja lebih efisien.

Aplikasi ini membantu UKM untuk memotong biaya, meningkatkan efisiensi dan meningkatkan kolaborasi. Mereka memungkinkan karyawan untuk mempertahankan pekerjaan mereka dalam satu tempat yang aman, serta berkolaborasi dan berbagi dokumen, spreadsheet, dan presentasi dengan rekan tim di seluruh perangkat.Di wilayah di mana bahasa resmi hidup berdampingan dengan ratusan dialek lokal, aplikasi seperti Google Translate telah menjadi penting dalam menjembatani kesenjangan komunikasi, terutama bagi pengguna yang bepergian di wilayah tersebut. Internet browser seperti Google Chrome serta aplikasi eCommerce, Ride Hailing, dan Travel yang populer di Tenggara Asia menggunakan layanan terjemahan untuk meningkatkan komunikasi secara real time antara pengguna dan penyedia layanan (Mishkin, F. S. :2007). Ini hanyalah beberapa dari banyak cara di mana Internet seluler mengubah kehidupan di Tenggara Asia. Karena sebagian besar aplikasi Internet seluler gratis untuk digunakan, mereka tidak menambah nilai moneter Internet Sektor ekonomi yang dicakup dalam penelitian ini, seperti e-Commerce, Ride Hailing, Media Online, dan Online Perjalanan. Namun, nilainya bagi pengguna dan UKM di wilayah tersebut tidak dapat dikecilkan.

Sebuah inovasi berhasil mentransformasi suatu sistem atau pasar yang eksisting, dengan memperkenalkan kepraktisan, kemudahan akses, kenyamanan, dan biaya yang ekonomis, dikenal sebagai Inovasi Disruptif (Disruptive Innovation). Istilah ini dilontarkan pertama kalinya oleh Clayton M.Christensen dan Joseph Bowerdi tahun 1995 lalu. "DisruptiveTechnologies: Catching the Wave", Harvard Business Review (1995). Inovasi Disruptif ini biasanya mengambil segmen pasar tertentu yang kurang diminati atau dianggap kurang penting bagi penguasa pasar, namun inovasinya bersifat breakthrough dan mampu meredefinisi sistem atau pasar yang eksisting. Munculnya Inovasi Disruptif jika tidak diantisipasi dengan baik oleh dunia usaha dapat menyebabkan kejatuhan seperti yang dialami KODAK dan NOKIA. Fenomena Inovasi Disruptif juga terjadi di Industri Jasa Keuangan yang telah men-disrupsi landscape ndustri Jasa Keuangan secara global.Mulai dari struktur industrinya, teknologi intermediasinya, hingga model pemasarannya kepada konsumen.

Keseluruhan perubahan ini mendorong munculnya fenomena baru yang disebut Financial Technology (Fintech). Pentingnya suatu FinTech diera sekarang ini dikarenakan 
masyarakat tidak dapat dilayani industri keuangan tradisional yang mana industri perbankan terikat aturan yang ketat serta keterbatasan industri perbankan dalam melayani masyarakat di daerah tertentu sehingga Masyarakat mencari alternatif pendanaan selain jasa industri keuangan tradisional sehingga Masyarakat memerlukan alternatif pembiayaan yang lebih demokratis dan transparan Biaya layanan keuangan yang efisien dan menjangkau masyarakat luas. Dari penjelasan di atas peneliti tertarik untuk menganalisa perkembangan e-conomy di ASEAN dengan judul "ANALISA E-CONOMY DI ASEAN (Studi Komparatif di Enam Negara ASEAN"

\section{LANDASAN TEORI}

\subsection{Industri 4.0}

Pemerintah Federal Jerman menghadirkan Industri 4.0 sebagai, struktur yang muncul di mana manufaktur dan sistem logistik dalam bentuk Cyber Physical Production System (CPPS) secara intensif menggunakan yang tersedia secara global jaringan informasi dan komunikasi untuk pertukaran informasi yang terotomasi secara luas dan di mana proses produksi dan bisnis dicocokkan (Bahrin,2016). Empat penggerak utama Industry 4.0 adalah Internet of Things (IoT), Industri Internet of Things (IIoT), pabrikan berbasis Cloud dan pabrikan pintar yang membantu mengubah proses pembuatan menjadi sepenuhnya digital dan cerdas (Erol,2016). Sembilan pilar Industri 4.0 akan mengubah produksi sel yang terisolasi dan dioptimalkan menjadi produksi yang terintegrasi, otomatis, dan dioptimalkan mengalir. Ini mengarah pada efisiensi yang lebih besar dan perubahan dalam hubungan produksi tradisional antara pemasok, produsen, dan pelanggan serta antara manusia dan mesin (M.Rubbmaan, 2012).

\subsection{Robotisasi}

Robot menjadi lebih mandiri, fleksibel, dan kooperatif dari hari ke hari dan pasti mereka akan berinteraksi satu sama lain dan bekerja dengan aman berdampingan dengan manusia dan belajar dari mereka (M.Rubbmaan, 2012). Robot otonom digunakan untuk melakukan metode produksi otonom lebih tepat dan juga bekerja di tempat-tempat di mana pekerja manusia berada terbatas untuk bekerja. Robot otonom dapat menyelesaikan tugas yang diberikan secara tepat dan cerdas dalam waktu yang diberikan membatasi dan juga fokus pada keamanan, fleksibilitas, fleksibilitas dan kolaboratif (Bahrin,2016).

\subsection{Internet of Things}

Internet of Things berarti jaringan di seluruh dunia objek yang saling berhubungan dan seragam itu berkomunikasi melalui protokol standar (E. Hodzic,2015). Internet of Things (IoT) juga harus dikenal sebagai Internet of Everything (IoE) yang terdiri dari Internet of Service (IoS), Internet of Manufacturing Services (IoMs), Internet of People (IoP), sistem tertanam dan Integrasi teknologi Informasi dan Komunikasi (IICT) (R.Neugbeur,2016). 
Konteks, omnipresence dan optimisasi adalah tiga fitur kunci dari IoT di mana konteks merujuk kemungkinan maju interaksi objek dengan lingkungan yang ada dan respons segera jika ada perubahan, kemahahadiran menyediakan informasi lokasi, kondisi fisik atau atmosfer suatu objek dan optimasi menggambarkan fakta-fakta itu objek saat ini lebih dari sekadar koneksi ke jaringan operator manusia pada antarmuka manusia-mesin. Itu rantai nilai harus cerdas, lincah dan jaringan dengan mengintegrasikan objek fisik, faktor manusia, cerdas mesin, sensor cerdas, proses produksi, dan jalur produksi bersama melintasi batas organisasi.

Perangkat lunak dan data adalah elemen kunci untuk perencanaan dan kontrol cerdas mesin dan pabrik di masa depan misalnya dalam hal penyimpanan di gudang, rak cerdas dan palet akan menjadi kekuatan pendorong modern manajemen persediaan. Sehubungan dengan pengangkutan barang - pelacakan dan penelusuran menjadi lebih cepat, lebih akurat dan aman.

\section{METODOLOGI PENELITIAN}

Penelitian ini bertujuan melihat perkembangan e-conomy di ASEN baik dalam populasi penggunaan, nilai kapitalisasi, pertumbuhan e-conomy, perilaku konsumen dalam penggunaan internet, dan fintech. Penelitian ini menggunakan pendekatan kualitatif deskriptif dengan menggunakan metode komparatif dan kualitatif, yaitu membandingkan suatu permasalahan dan menganalisis data dan hal-hal yang berhubungan dengan angkaangka yang digunakan untuk menganalisis masalah yang sedang diteliti. Sampel dalam penelitian ini adalah 6 negara ASEAN meliputi Thailand, Vietnam, Singapura, Indonesia, Philipina dan Malaysia.

\section{PEMBAHASAN}

Valuasi Nilai Internet di ASEAN

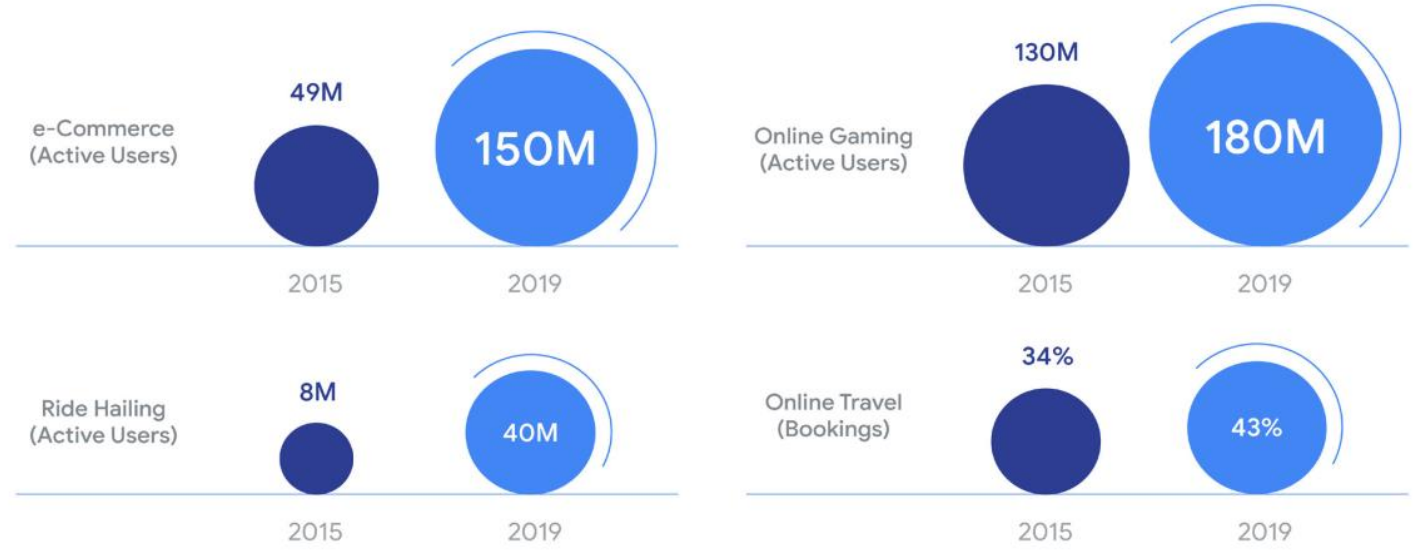

Gambar 4.1 Valuasi Nilai Pengguna Internet di ASEAN

Sumber: Temasek: 2019

Ekonomi Internet Asia Tenggara melewati titik belok utama pada tahun 2018. Dan terus berlanjut untuk mempercepat pertumbuhan yang cepat. Didukung oleh adopsi yang 
cepat dan preferensi konsumen yang berubah, sehingga berhasil dalam tonggak sejarah mencapai angka kapitalisasi sebesar \$ 100 miliar. Peneliti memperkirakan bahwa ekonomi Internet Asia Tenggara telah melonjak hampir 40\% dari tahun lalu hingga terlampaui \$100 miliar dalam nilai barang dagang bruto (GMV) pada tahun 2019 di Travel Online, e-Commerce, Media Online dan sektor Hide Ride. Dengan tingkat pertumbuhan tahunan gabungan (CAGR) 33\%, nilai Internet ekonomi meningkat lebih dari tiga kali lipat antara 2015 dan 2019. Laju pertumbuhan ini telah melampaui semua harapan. Pada tingkat ini, ekonomi Internet Asia Tenggara berada di jalur untuk mencapai \$ 300 miliar pada tahun 2025, melampaui proyeksi awal kami pada tahun 2016 sebesar \$ 100 miliar. Selain menghabiskan lebih banyak waktu di Internet seluler, banyak juga menghabiskan uang untuk layanan online dan produk. Ekonomi Internet sekarang melibatkan 180 juta orang di Asia Tenggara, atau sekitar satu dalam dua pengguna Internet.

Bukan hanya tingkat penetrasi yang menonjol; kecepatan di mana wilayah telah mengadopsi ekonomi digital juga mencolok. Ambil contoh e-Commerce. Pada 2015, sekitar 49 juta orang membeli atau menjual barang secara online. Saat ini, jumlah itu meningkat tiga kali lipat menjadi 150 juta orang. Permintaan untuk layanan Hide Ride juga telah meledak, dengan jumlah pengguna aktif menggelembung lima kali untuk mencapai lebih dari 40 juta hari ini, dari hanya delapan juta pada tahun 2015.

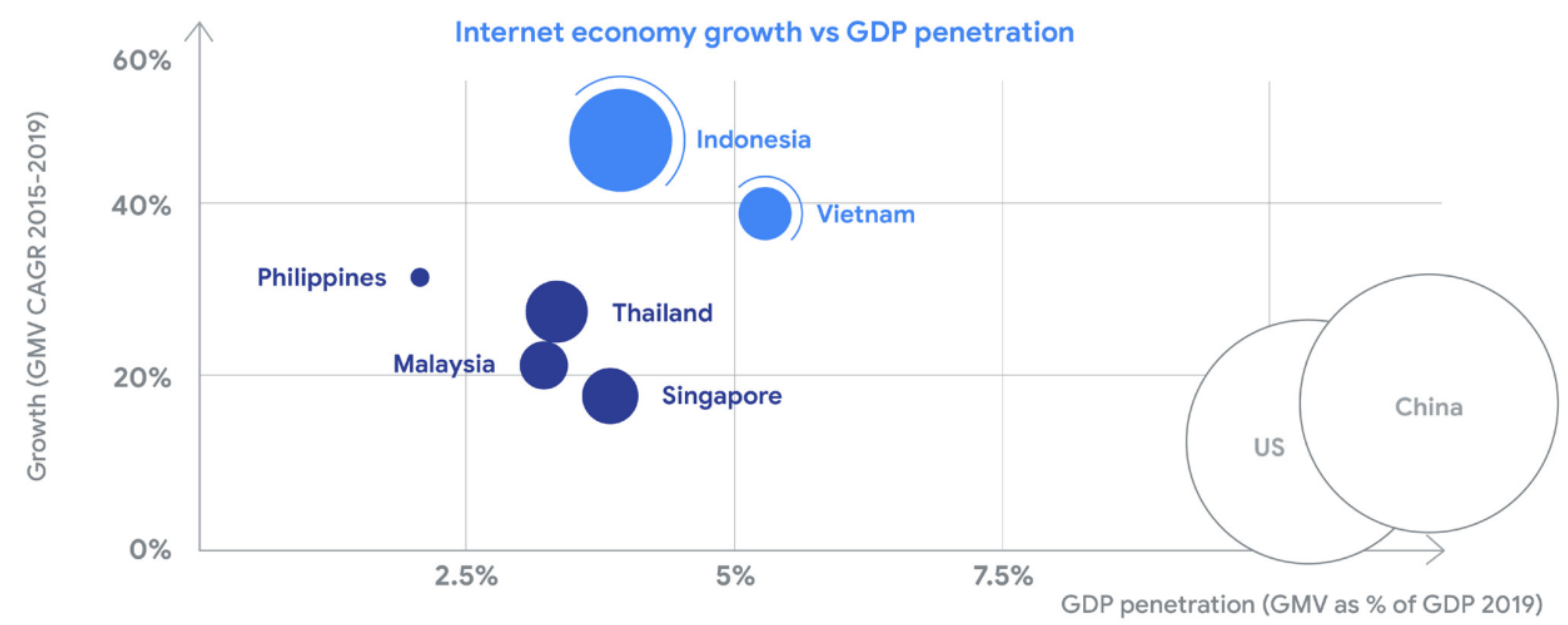

Gambar 4.2 Internet economy growth vs GD Penetration

Sumber: Bain \& Company:2019

Baik e-commerce dan Ride Hailing, yang termasuk layanan Pengiriman Makanan, mengalami ledakan permintaan sebagai hasil dari adopsi cepat dan perubahan mendasar dalam perilaku konsumen. Dalam rentang tersebut dari beberapa tahun, e-Commerce dan Ride Hailing telah menjadi bagian integral dari kehidupan sehari-hari bagi jutaan orang Orang Asia Tenggara, terutama yang tinggal di kota-kota besar. Mereka menawarkan kenyamanan, nilai, dan akses ke layanan dan produk yang sebelumnya sulit diperoleh. Misalnya, aksesibilitas luas dan keterjangkauan layanan Ride Hailing di Metropolitan yang 
ramai daerah mendorong banyak orang Asia Tenggara untuk memikirkan kembali kebutuhan memiliki kendaraan. Ride Hailing adalah hasil imbang besar untuk orang-orang di kota yang ramai seperti Bangkok, Jakarta dan Kuala Lumpur, tempat kepemilikan kendaraan pribadi mahal, berkontribusi terhadap polusi udara dan dikaitkan dengan kemacetan yang membuat frustrasi. Demikian pula, konsumen mengandalkan layanan Pengiriman Makanan untuk makanan yang seharusnya mereka miliki masak di rumah atau beli dari penjual makanan. Untuk kelas menengah yang muncul dan semakin sadar waktu, kenyamanan memiliki perpipaan makanan panas yang dikirim ke depan pintu seseorang sangat dihargai. Konsumen seperti itu perilaku telah menjadi norma, khususnya di antara keluarga berpenghasilan ganda.

\section{Perbandingan Internet Economy di Enam Negara}

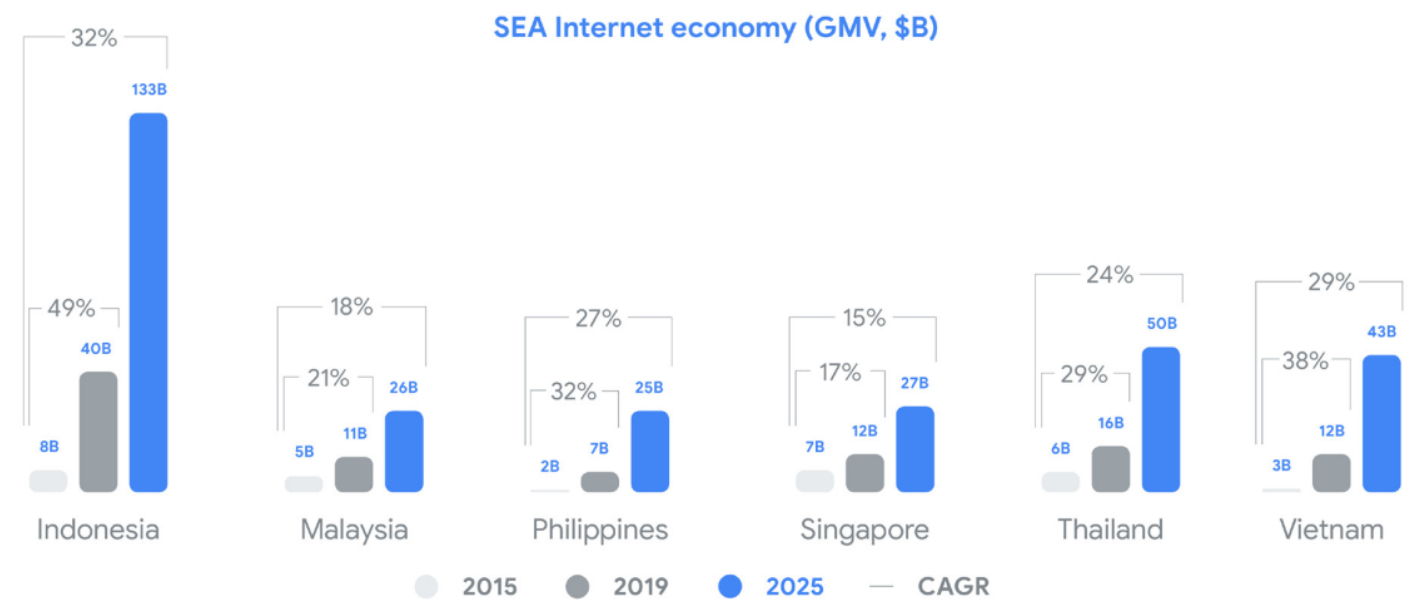

\section{Gambar 4.3 Internet Economy di enam Negara}

Sumber: Bain \& Company:2019

Diperkirakan \$ 40 miliar pada tahun 2019, ekonomi Internet Indonesia memiliki lebih dari empat kali lipat sejak 2015 dengan tingkat pertumbuhan rata-rata 49\% setahun. Sebagai ekonomi Internet terbesar dan paling cepat berkembang di Indonesia wilayah, Indonesia berada di jalur yang tepat untuk melewati batas $\$ 130$ miliar pada tahun 2025. Secara khusus, sektor e-Commerce dan Ride Hailing menembaki semua silinder, didorong oleh persaingan yang ketat antara Indonesia dan daerah pemain. Semua sektor juga mendapat manfaat dari adopsi yang tumbuh dari Pembayaran Digital. Investasi mengikuti, dengan lebih sedikit tetapi kesepakatan lebih besar.

Tahun ini, Indonesia berada di jalur yang sesuai dengan Indonesia rekor didirikan pada 2018, ketika hampir \$ 4 miliar dinaikkan. Putaran pendanaan besar diselesaikan oleh Unicorn Indonesia seperti Bukalapak, Gojek, Tokopedia dan Traveloka memimpin. Berbasis di Singapura Grab juga telah mengumumkan komitmen multi-miliar dolar untuk berinvestasi di negara itu selama beberapa tahun ke depan. Ekonomi internet Vietnam juga sedang booming, karena mencapai \$ 12 miliar pada tahun 2019 dengan 38\% tahunan tingkat pertumbuhan sejak 2015. Dengan GMV ekonomi Internet-nya ditetapkan untuk menyumbang 
lebih dari 5\% dari negara PDB pada 2019,10 Vietnam muncul sebagai yang paling digital dari semua ekonomi di kawasan ini. e-Commerce adalah kuncinya pembalap di belakang angka yang mengesankan, di mana pasar homegrown seperti Sendo dan Tiki bersaing dengan pemain regional seperti Lazada dan Shopee.

Dinamika ini membuka peluang bagi UKM kewirausahaan Vietnam, yang telah melonjak onboard ekonomi Internet untuk melakukan bisnis. Kepercayaan investor di Vietnam, yang paling banyak didanai ketiga ekonomi di kawasan setelah Indonesia dan Singapura, terus meningkat. Selama empat tahun terakhir, Vietnam. Ekonomi internet telah menarik hampir \$ 1 miliar dalam pendanaan, dengan 2019 sejalan untuk menjadi tahun rekor. Sementara Indonesia dan Vietnam memimpin, Malaysia, Filipina, Singapura, dan Thailand juga berkinerja kuat. Bahkan, dengan tingkat pertumbuhan rata-rata antara 20 dan $30 \%$ per tahun sejak 2015, negara-negara ini menumpuk sangat baik terhadap banyak negara lain secara global.

Perubahan Fundamental pada Perubahan Perilaku di E-conomy
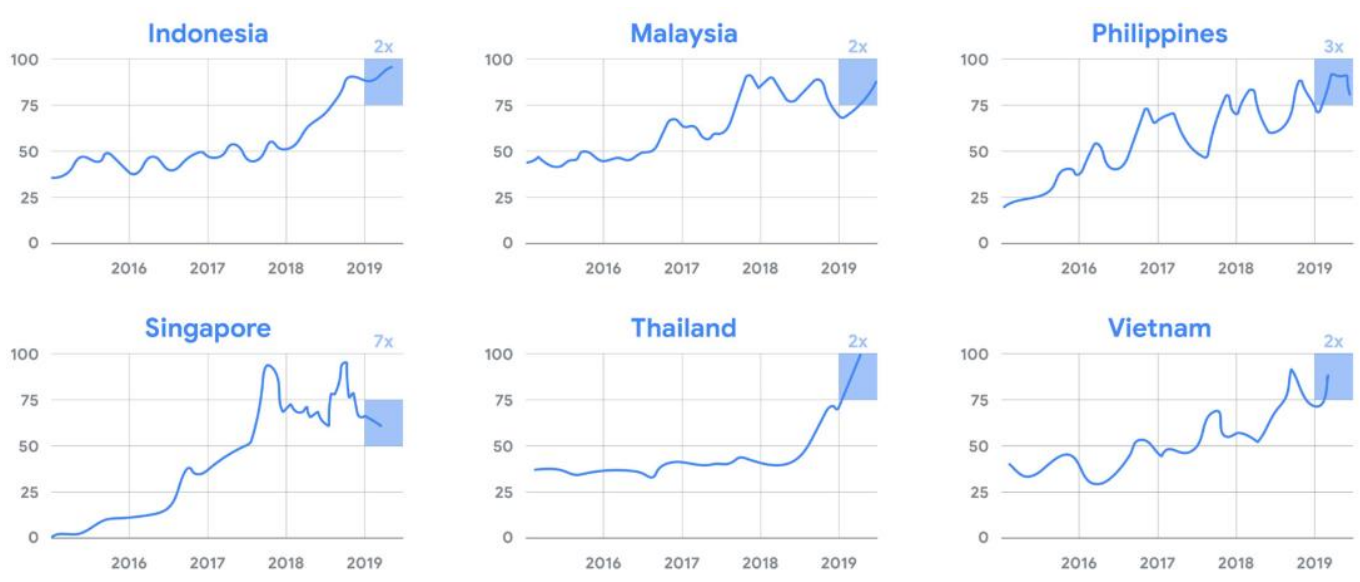

Gambar 4.4 Google Trends for selected e-Commerce promotions

Sumber: diolah oleh peneliti

Aplikasi e-Commerce terkemuka di kawasan beralih ke hiburan sebagai strategi promosi. Beberapa aplikasi tampilkan video streaming langsung dari influencer populer "unboxing" gadget dan memberikan ulasan tentang favorit mereka merek. Yang lain menawarkan pilihan kepada pembeli untuk mengobrol dengan "penjual sosial" dan bersaing dalam lelang langsung, yang membuat proses pembelian lebih interaktif. Pendekatan semacam itu telah mendapatkan daya tarik terutama di Indonesia negara-negara seperti Vietnam dan Indonesia. Banyak dari inisiatif ini dikombinasikan dengan unsur-unsur "gamification". Misalnya, pengguna sering diundang untuk bekerja dengan satu sama lain selama festival belanja untuk menurunkan biaya barang yang ditawarkan.

Dalam permainan terminologi, ini mirip dengan melawan atau menyerang "bos". Melibatkan pengguna dengan gamification juga menghasilkan wawasan berharga tentang perilaku dan preferensi konsumen, yang membantu perusahaan e-Commerce 
menyempurnakan penawaran layanan dan produk mereka melalui Machine Learning. Pasar tidak bekerja hanya untuk mendorong permintaan. Mengetahui bahwa pengguna dimanjakan dengan pilihan kapan datang ke tempat mereka dapat berbelanja, perusahaan $e$-Commerce memilih untuk juga fokus pada sisi penawaran dengan memastikan bahwa platform mereka ditumpuk dengan produk berkualitas baik dan merek asli dari yang andal penjual. Untuk pasar-pasar terkemuka di kawasan ini, bekerja dengan penjual untuk meningkatkan penjualan dan keuntungan sekarang adalah aprioritas strategis, mengingat bahwa penjual cenderung "lebih lengket" terhadap platform dibandingkan dengan pengguna.

\section{Financial Technology di ASEAN}

Funding for SEA Unicorns (\$B)

Unicorns

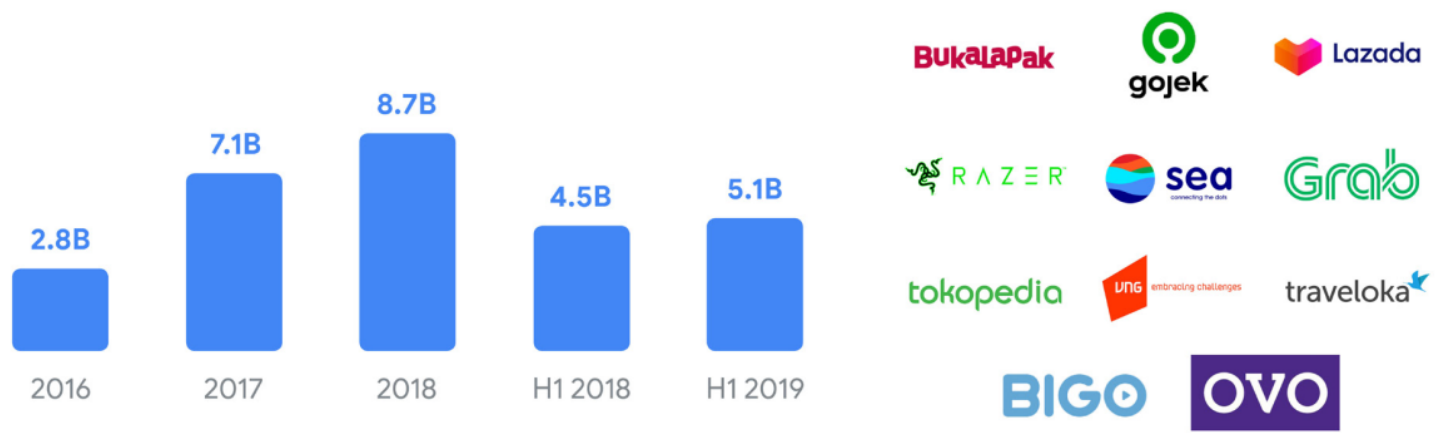

Gambar 4.5 Pendanaa Unicorns di ASEAN menggunakan FinTech

Sumber: Laporan Google:2019

Tidak mengherankan, sebagian besar dana terus mengalir ke daerah perusahaan teknologi terbesar. Selama empat tahun terakhir, Asia Tenggara Unicorn menarik \$ 24 miliar dari total \$ 37 miliar yang dikumpulkan. Pada tahun 2019, Bigo dan OVO, platform Pembayaran, Imbalan, dan Layanan Keuangan Indonesia, bergabung grup eksklusif ini, menjadikan jumlah Unicorn di wilayah ini menjadi 11.

Daftar sekarang terdiri dari Bigo, Bukalapak, Gojek, Grab, Lazada, Razer, OVO, Grup Laut, 23 Traveloka, Tokopedia, dan VNG.24 Semua ini sebagian besar merupakan hasil dari investor yang menggandakan taruhan mereka pada kelompok sukses ini perusahaan dengan rekam jejak yang terbukti. Setelah Unicorn mencapai ukuran dan skala tertentu, mereka mampu untuk menarik investasi besar dari beberapa investor swasta dan investor institusional terbesar di dunia. Investor ini mungkin tidak tertarik dengan startup teknologi yang lebih kecil, yang ditargetkan oleh usaha tahap awal perusahaan modal sebagai gantinya. 


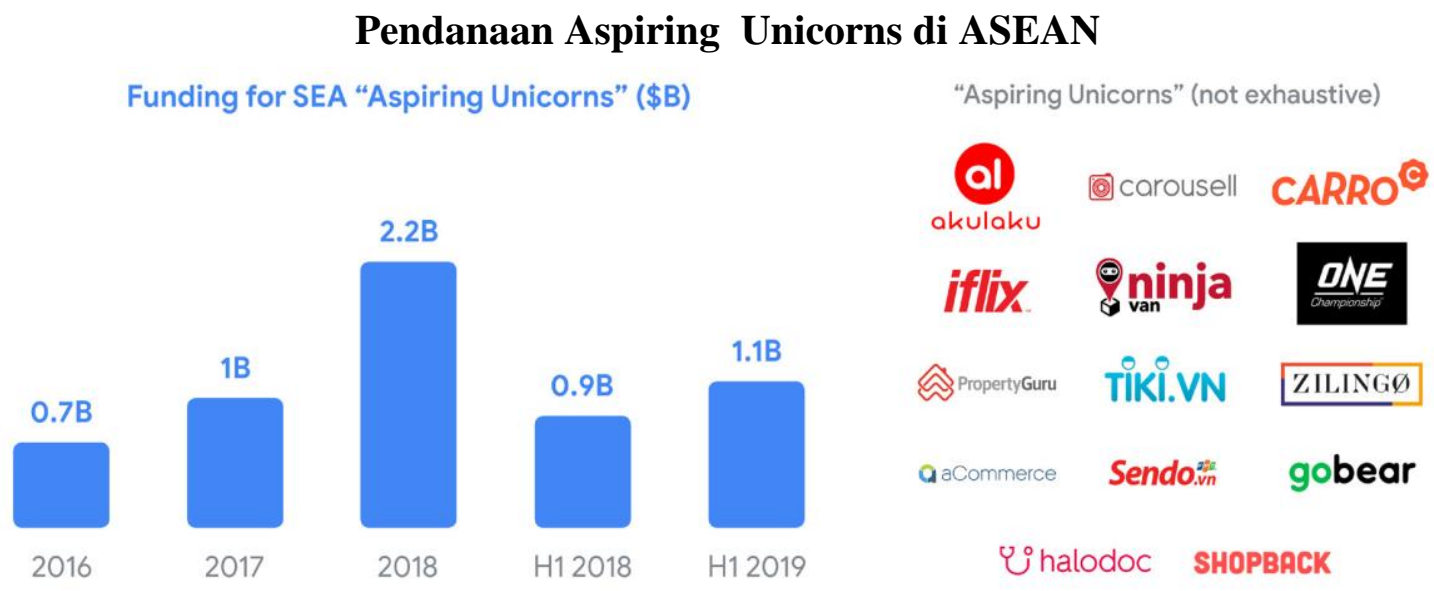

Gambar 4.6 Pendanaan Aspiring Unicorns

Sumber: Laporan Google:2019

Ada sekelompok hampir 70 perusahaan bernilai antara \$ 100 juta dan \$1 miliar. Mereka menggambar sekitar \$ 1,1 miliar dalam pendanaan pada paruh pertama 2019, melampaui \$ 900 juta yang dikumpulkan pada periode yang sama tahun lalu Perusahaan di tingkat ini - apa yang kita sebut "Aspiring Unicorn" 25 - telah mengumpulkan \$ 5 miliar sejak 2016. Aspiring Unicorn termasuk perusahaan seperti Carousell, pasar e-Commerce konsumen ke konsumen, ONE Championship, properti media olahraga, dan Zilingo, platform e-Commerce mode. Ada juga pasar vertikal seperti Carro, yang didedikasikan untuk industri otomotif, dan PropertyGuru, yang mengkhususkan diri dalam real estat. pasar e-Commerce seperti Sendo.vn dan Tiki.vn telah memutuskan untuk fokus di pasar Vietnam. I

Sementara Unicorn Asia Tenggara bertujuan untuk berekspansi secara regional dan melakukan diversifikasi ke berbagai sektor, Aspiring Unicorn masih fokus membangun parit di sektor atau pasar khusus mereka - strategi itu mungkin membayar di waktu yang akan datang. Bersama-sama, Unicorn dan Aspiring Unicorn kemungkinan telah menyerap sebagian besar pendanaan. Namun, lebih dari \$ 7 miliar dalam pendanaan digunakan untuk lebih dari 3.000 Internet startup ekonomi dalam empat tahun terakhir. Banyak dari ini memvalidasi mereka model bisnis dan menguji kesesuaian pasar produk mereka. Mereka punya sedikit untuk menunjukkan dalam hal pendapatan dan model monetisasi mereka masih belum terbukti. Faktanya, banyak yang mungkin tidak berhasil dan sebagian besar mungkin harus berputar ide bisnis asli mereka. Tetapi bagi mereka yang menemukan formula yang tepat, hasilnya akan sangat besar.

\section{KESIMPULAN}

Berdasarkan dari pembahasan pada bab sebelumnya dapat disimpulkan sebagai berikut:

- Pertumbuhan cepat dan lebih cepat: Asia Tenggara kecepatan ganda. Ekonomi internet di Malaysia, Thailand, Singapura dan Filipina tumbuh antara 20\% dan 30\% setiap tahun, tanpa tanda-tanda melambat turun. Ini adalah prestasi yang luar biasa 
dibandingkan dengan daerah lain, tetapi bukan pertunjukan terbaik di Tenggara Asia. Dua penentu kecepatan di wilayah tersebut adalah Indonesia dan Vietnam, yang memimpin pertumbuhan tingkat lebih dari $40 \%$ per tahun.

- Waktu adalah uang: bersaing untuk keterlibatan pengguna. Perusahaan mengalihkan fokus mereka dari mengakuisisi pelanggan baru untuk mendorong keterlibatan. Tujuan mereka adalah untuk meyakinkan pengguna agar tetap di platform mereka lebih lama, dengan keyakinan bahwa pembelian akan mengikuti. Bersaing untuk keterlibatan pengguna, perusahaan telah memperluas cakupannya lintas sektor, pindah ke layanan baru, gamifikasi promosi, dan streaming konten yang memikat. Ini mempunyai memicu persaingan yang lebih ketat, sambil memberi pengguna lebih banyak pilihan dan harga lebih rendah.

- Peluang pertumbuhan di luar Metros. Pertumbuhan ekonomi Internet belum menyebar merata di seluruh Asia Tenggara. Tujuh wilayah Metropolitan, yang menampung hanya $15 \%$ dari wilayah tersebut populasi, masih menyumbang lebih dari $50 \%$ dari ekonomi Internet. Rata-rata, orang yang tinggal di ini Wilayah metro membeli online enam kali lebih banyak daripada yang tinggal di tempat lain. Ekonomi Internet, bagaimanapun, telah potensi untuk tumbuh dua kali lebih cepat di daerah di luar kotakota besar, membawa semua orang Asia Tenggara.

- Layanan Keuangan Digital mencapai disrupsi. Adopsi Pembayaran Digital akhirnya mencapai titik belok dan diperkirakan akan melampaui \$ 1 triliun pada tahun 2025, terhitung hampir satu dalam setiap dua dolar dihabiskan di wilayah tersebut. Layanan Keuangan Digital Lainnya masih baru tetapi mendapatkan daya tarik. Ini model bisnis yang didukung teknologi berada pada posisi terbaik untuk memberikan populasi yang kekurangan pembayaran di Asia Tenggara akses ke Layanan Keuangan. Sementara pendatang baru dan pemain mapan bersaing dan bermitra untuk mengatasi peluang ini, peraturan yang mendukung akan memainkan peran penting.

\section{DAFTAR PUSTAKA}

Abrar, Hafiza.(2016). Analisis Pengaruh Keterbuakaan Perdagangan (Trade Oppenes) Terhadap Inflasi di Indonesia tahun 2000-2015. Universitas Andalas:Padang

Allen, Franklin, et al. (2013). Does Finance Accelerate or Retard Growth? Theory and Evidence. Global Citizen Foundation Working Paper 4.

Asari, F. F. A. H., et all. (2011). A Vector Error Correction Model (VECM) Approach in Explaining the Relationship Between Interest Rate Inflation Towards Exchange Rate Volatility in Malaysia. World Applied Sceience Journal. (ISSN : 1818-4952).

Bardiev, A. N., dan Saunoris, J.W. (2016). Financial development and the shadow economy.Economic Modelling, No. 57. 
Bittencourt, M., Gupta, R., Stander, L. (2014), Tax evasion, financial development and inflation: Theory and empirical evidence. Journal of Banking and Finance, 41, 194208.

Bose, N., Capasso, S., dan Wurm, M.A. (2012). The impact of banking development on the size of shadow economies. Centre for Studies in Economics and Finance: Working Paper, No. 207.

Cao Lu, dan Zhou Xin. (2010). Impulse-Response Function Analysis : An application to macroeconomic data of China. Departmen of Economics and Society, Hogskolan Dalarna.Swaden.

D. H. Vo, dan T. H. Ly. (2014). Measuring the Shadow Economy in the ASEAN Nations : The MIMIC Approach. International Journal of Economics and Finance, vol. 6, No. 10.

E. Hozdić, Smart Factory for Industry 4.0: A Review, International Journal of Modern Manufacturing Technologies, ISSN 2067-3604, (Vol. VII, No. 1 / 2015) 28-35.

Elgin, Ceyhun, dan Oztunali, Oguz. (2012 ). Shadow Economies around the World: Model Based Estimates. Working Paper

MAK. Bahrin, MF. Othman, NH. Nor, MFT. Azli, Industry 4.0: A Review on Industrial Automation and Robotic, Jurnal Teknologi (Sciences \& Engineering), eISSN 2180 3722 (2016) 137-143.

Mishkin, F. S. (2007). The Economic of Money, Banking, and Financial Markets (8th ed.) Boston: Addison-Wesley.

M. Rüßmann, M. Lorenz, P. Gerbert, M. Waldner, Industry 4.0: The Future of Productivity and Growth in Manufacturing Industries, (April 09, 2015) 1-14

R. Neugebauer, S. Hippmann, M. Leis, M. Landherr, Industrie 4.0- Form the perspective of apllied research, 49th CIRP conference on Manufacturing systems (CIRP-CMS 2016), 2-7.

S. Erol, A. Jäger, P. Hold, K. Ott, W. Sihn, Tangible Industry 4.0: a scenario-based approach to learning for the future of production, 6th CLF - 6th CIRP Conference on Learning Factories, Procedia CIRP 54 (2016) $13-18$. 